\title{
How the mighty have fallen? International politics in the Trump era
}

International Politics Reviews (2017) 5, 47-50. https://doi.org/10.1057/s41312-017-0042-4

As we approach the winter of 2017, we now have more than nine months of experience with Donald Trump as president of the United States. His early actions have cast a shadow over the international order and the direction of US foreign policy. Despite a large departure in rhetoric and rupture in decorum, some analysts see more continuity in the early actions of the Trump administration, given the placement of traditional internationalist stalwarts in positions of authority such as James Mattis as Secretary of Defense. However, with the Trump administration repudiating Obama administration policies on climate change, the Iran nuclear deal, and the Trans-Pacific Partnership (TPP), there is plenty of evidence to suggest more significant changes are afoot as the United States moves to a more transactional, America First concept of US international engagement.

Such seismic shifts are not solely happening in the United States. The UK's decision to withdraw from the European Union is another example. Perhaps as, if not more, important is the rise in nationalism and democratic decay that we have observed in a number of countries, including the United States but also Turkey, the Philippines, among others.

In the lead up to the election of Donald Trump, the reemergence of serious geopolitical tensions was already on display, as China became more assertive in the South China Sea and Russia occupied Crimea and sought to destabilize democratic governments through cyber operations.

While the books reviewed in this issue were largely complete before the new US administration took office, the darkened international outlook shapes the reviews and responses. In the case of, All Measures Short of War, the author Tom Wright was able to update the book as it went to press on the potential implications of a Trump presidency. Wright had been one of the most clear-eyed analysts of Trump's worldview, and yet, his book was largely written with an eye toward a Hillary Clinton presidency and the advice she would need to address re-energized geopolitical competition from rival powers, namely China and Russia, and still defend the 
liberal order. His basic premise is that previous post-Cold War US administrations thought global convergence was possible, that China and Russia could be brought into the fold of the liberal international order and come to embrace it.

The reviewers, Nuno Monteiro, Chris Preble, and Kori Schake all find this book an important contribution to thinking through the challenges of the reassertion of geopolitics. Preble, whose own inclinations are more on the side of restraint, questions whether or not the American public, after the interventions in Afghanistan and Iraq, has the appetite to underwrite Wright's call for vigorous reaffirmation of the liberal world order and geopolitical competition. Monteiro worries that the scope for "responsible competition" short of war is limited, as measures intended to check China and Russia's ambitions may well lead to deeper conflict. He suggests that the choices are between "responsible accommodation" to Chinese and Russian aspirations for regional spheres of influence and "risky competition" that may get out of hand. Schake, whose is more sympathetic to Wright's project, sees the liberal order as more robust, that some contestation with countries like Russia was inevitable, and that the policy recommendations that flow from Wright's analysis ought to be more assertive than sustained engagement around the world.

In his epilogue, Wright addresses the elephant in the room-Trump-head-on by evoking Philip Roth's novel The Plot Against America. In Roth's imagined narrative, Nazi sympathizer Charles Lindbergh wins the presidency in 1940 and yields an America First administration that is openly antiSemitic. The parallel is of a man who won the presidency as a nationalist hostile to democratic and liberal norms at home and abroad. Four or even eight years will test the order like never before and potentially accelerate geopolitical competition.

A second exchange in this issue is somewhat orthogonal but related to the debate over the liberal international order. Chelsea Clinton and her co-author Devi Sridhar have an important book Governing Global Health in which they trace the evolution of the major institutions in the global health space over the last few decades. In the 2000s, global health experienced an unprecedented increase in resources and attention, as the George W. Bush administration embraced an ambitious attempt to arrest the global AIDS epidemic through financial support for a bilateral program and a new public private partnership, the Global Fund to Fight AIDS, TB, and Malaria. As the latters name implies, the Global Fund had a more ambitious agenda than a single disease. The spike in funding and salience of global health was also vigorously supported by the Bill and Melinda Gates foundation who underwrote billions of dollars of projects around the world, making them as important as traditional players in the global health arena as the World Health Organization (WHO).

Through the lens of principal-agent theory, Clinton and Sridhar survey how the main multilateral organizations like WHO, the Global Fund, the World Bank, and Gavi the vaccine alliance operate. They explain why the principalsnamely states - have created new, leaner publicprivate partnerships such as the Global Fund and Gavi rather than seek to reorganize aging multilateral institutions like WHO.

The three reviewers, Timothy Mackey, Jeremy Youde, and myself, see a lot of virtues in their book, and our criticisms are mostly about how the mélange of actors working in this space are supposed to coordinate and be collectively effective in light of sustained challenges of infectious disease like Ebola and Zika. The defects of organizations like WHO are as much a product of choices made by the principals to cut investments in WHO's capacity while at the same time saddling the organization with ambitious new mandates to address a wider array of functions.

Clinton and Sridhar are alarmed by what the Trump administration's victory means for global 
health governance going forward. The 2008 financial crisis was the high water mark for global health, and as David Fidler has written elsewhere, the subsequent years were ones of consolidation with the international community trying to make do with flat if not fewer resources. The 2014 Ebola crisis demanded an international response that led to emergency mobilization of resources to ward off potentially calamitous continental and global contagion.

The Trump administration's proposed budgets for development assistance threaten to gut US commitments to global health, undermine its technical capacity to understand and combat emergent health problems through entities such as the Centers for Disease Control and the National Institutes of Health. While the Congress thus far has not indulged the scope of cost-cutting the Trump administration has proposed, the new administration has put down a marker that may well become partially enacted in time. The real question is how will the new administration handle a global health emergency should it emerge. Unlike the Obama administration, which reacted to the Ebola epidemic with the appropriate commitment that the crisis required, the Trump administration may not be so inclined and may not have as deep a bench of public officials who can lead. We should remember that the Obama's administration efforts, along with those of other countries like the UK, were a second-best solution after WHO could not and did not get out in front to prevent the outbreak from becoming a crisis. The international order of global health is showing its age and, if anything, is in need of serious renovation that a Trump administration will unlikely deliver.

A third exchange in this issue complements these other two. Alexandru Grigorescu's book Democratic Intergovernmental Organizations? traces the evolution of international organizations throughout the twenty-first century as stakeholders sought to make them more democratic.
Though advocates for democratization did not always get what they wanted, Grigorescu argues that a particular form of bargaining ensued that often resulted in organizations being different than they were before. Klaus Dingwerth, Felicity Vabulas, and Joel Westra are the reviewers and raise a number of questions about the conceptual underpinning of the argument.

Vabulas in her piece raises a point germane to the previous discussion about Trump's impact on the liberal order. She asks what impact democratic erosion in countries' domestic polities will have on how international organizations evolve in the coming years. What impact would a normative environment that is more overtly nationalist have on international organizations? What are the ramifications of the Trump administration's withdrawal from the TPP, UNESCO, and EITI (a major transparency initiative for extractive industries)? Will the UK's decision to exit the European Union create more pressures to narrow the perceived democratic deficit? Are Chinese-led international organizations like the Asian Investment and Infrastructure Bank subject to a different set of norms? I expect Grigorescu and the reviewers will weigh in with important contributions in the coming years.

In his review article "The Power and Perils of International Law: A Review Essay on Lawfare, Constructivism and International Lawpower" Ryder McKeown from the University of Toronto, argues that the historical divide between power and international law is breaking down in a modern international system that is at once anarchical, competitive, and highly legalized. McKeown dissects Bower's Norms without the Great Powers: International Law and Changing Social Standards in World Politics, Dill's Legitimate Targets? Social Construction, International Law and US Bombing and Kittrie's Lawfare: Law as a Weapon of War with a particular focus on the key concepts of power, asymmetry, legal effects, logics of behavior, and 
the normative status of international law in the world today. McKeown's piece makes a contribution to this field in that he demonstrates how these three scholars' insights may be utilized to create a new research agenda that takes international law seriously as an object of study but views legalism through the prism of conflict rather than cooperation. Such an agenda, argues McKeown, would begin by leveraging traditional insights about power, interests, and strategy to explain how law is a unique form of power. He provides the theoretical foundations for a realist concept of "lawpower" as a pool of resources that different actors can leverage for their own ends.
And last, but certainty not least, there are a number of short reviews from younger scholars to keep you abreast of some of the latest books in the field of international relations. We hope you enjoy this issue and as always your feedback is greatly welcome.
Joshua W. Busby Austin, TX, USA. E-mail: busbyj@utexas.edu

Michael John Williams New York University, New York, USA. 